\title{
Perlindungan Hak Cipta Dalam Pelanggaran Hak Cipta Logo Cap Jempol
}

\author{
Desi RatnaSari \\ 155100017, 785567874 \\ Fakultas Komputer \\ desiratnasari@institusi.ac.id
}

\begin{abstract}
komputer teknologi merupakan persyaratan penting untuk mengakses dan menggunakan informasi, mempercepat transfer teknologi dan mendorong pertumbuhan produktivitas. Pada saat yang sama waktu, komputer produk perangkat lunak yang mungkin yang paling berat dilindungi dari semua bentuk berbasis pengetahuan produk. Berdasarkan Perjanjian TRIPS, program komputer sekarang memenuhi syarat untuk perlindungan hak cipta sama seperti setiap karya sastra lain, serta untuk bentuk lain perlindungan IP, termasuk dengan paten di beberapa negara, seperti Amerika Serikat. Mengembangkan negara, tentu saja, memiliki berbagai persyaratan untuk aplikasi perangkat lunak komputer di mereka industri, rumah sakit, sekolah dan kantor pemerintah.,dengan Microsoft sebagai pemain utama, mendominasi pasar global untuk produk ini. Perangkat lunak industri negara-negara berkembang, bahkan di India, adalah kebanyakan absen dari program komputer dikemas sector. 20 Hak cipta yang paling penting dalam industri perangkat lunak komputer ke rak-off- aplikasi bisnis sektor. Tidak seperti aplikasi perangkat lunak dipesan lebih dahulu, produk ini memiliki mass market dan dapat dengan mudah disalin. Perlindungan hak cipta memungkinkan perusahaan untuk mencegah menyalin,persaingan batas dan harga biaya monopoli untuk produk ini.

Hal ini juga mungkin membatasi persaingan dalam pengembangan aplikasi antar-operasi,melalui tindak pada inovasi oleh reverse engineering. Dalam TRIPS, negara-negara berkembang diperbolehkan fleksibilitas untuk memungkinkan reverse engineering perangkat lunak,sehingga masalah ini dapat dihindari jika nasional undang-undang hak cipta yang dirancang tepat. Sebagai ukuran lain praktis, lebih luas penggunaan berbagai open source software produk,di mana kode sumber tersedia tidak seperti perangkat lunak berpemilik,dapat diterima atau beberapa di industri berpendapat bahwa dengan penegakan hak cipta lebih kuat,sumber tertutup karena pengembang proprietary mungkin lebih bersedia untuk membuat kode sumber tersedia untuk pengembang perangkat lunak dalam mengembangkan negara. Pada saat ini sebagian besar negara memiliki perangkat lunak dan program komputer yang dilindungi hak cipta.
\end{abstract}

Kata Kunci : Hak Cipta dan Perlindungan. 


\section{A. INTRODUCTION}

\section{HAK \\ INTELEKTUAL}

Kekayaan intelektual adalah kekayaan yang timbul dari kemampuan intelektual manusia yang dapat berupa karya di bidang teknologi, ilmu pengetahuan, seni dan sastra. Karya ini dihasilkan atas kemampuan intelektual melalui pemikiran, daya cipta dan rasa yang memerlukan curahan tenaga, waktu dan biaya untuk memperoleh "produk" baru dengan landasan kegiatan penelitian atau yang sejenis. Dalam pasal 7 TRIPS (tread related aspect of intellectual property right) dijabarkan tujuan dari perlindungan hak dan penegakan HAKI, yaitu bertujuan untuk mendorong timbulnya inovasi, pengalihan, penyebaran teknologi, dan diperolehnya manfaat bersama antra penghasil dan penggunaan pengetahuan teknologi, menciptakan kesejahteraan sosial dan ekonomi, serta keseimbangan antara hak dan kewajiban.

PRINSIP-PRINSIP HAK KEKAYAAN INTELEKTUAL
Prinsip-prinsip yang terdapat dalam hak kekayaan intelektual yaitu :

\section{Prinsip Ekonomi}

Prinsip ekonomi, yaitu hak intelektual berasal dari kegiatan kreatif suatu kemauan daya pikir manusia yang diekspresikan dalam berbagai bentuk yang akan memberikan keuntungan kepada pemilik yang bersangkutan.

2. Prinsip Keadilan Prisip keadilan, yaitu di dalam menciptakan sebuah karya atau orang yang bekerja membuahkan hasil suatu dari kemampuan intelektual dalam imu pengetahuan, seni, dan sastra yang akan mendapat perlindungan dalam pemilikannya.

3. Prinsip Kebudayaan

Prinsip kebudayaan, yaitu perkembangan ilmu pengetahuan, sastra dan seni untuk meningkatkan kehidupan manusia. Dengan menciptakan suatu karya dapat meningkatkan taraf kehidupan, peradaban, dan martabat manusia yang akan memberikan keuntungan bagi masyarakat, bangsa, dan negara. 


\section{Prinsip Sosial \\ Prinsip sosial (mengatur kepentingan manusia sebagai warga negara), artinya hak yang diakui oleh hukum dan telah diberikan kepada individu merupakan suatu kesatuan sehingga perlindungan diberikan berdasarkan keseimbangan kepentingan individu dan masyarakat.}

\section{KLASIFIKASI HAK \\ KEKAYAAN \\ INTELEKTUAL}

berdasarkan WIPO hak atas kekayaan intelektual dapat dibagi menjadi dua bagian, yaitu hak cipta (copyright), dan hak kekayaan industri (idustrial property rights).

Hak kekayaan industri adalah hak yang mengatur segala sesuatu tentang milik perindustrian, terutama yang mengatur perlindungan hukum. Hak kekayaan Industri (idustrial property rights) berdasarkan pasal

1 Konvensi Paris mengenai Perlindungan Hak Kekayaan Industri Tahun 1883 yang telah direvisi dan di amandemen pada tanggal 2 Oktober 1979, meliputi :
A. Paten
B. Merek
C. Varietas tanaman
D. Rahasia dagang
E. Desain industri
F. Deasin tata letak sirkuit terpadu

\section{DASAR HUKUM HAK KEKAYAANINTELEKTUAL DI INDONESIA}

Pengaturan hukum terhadap hak kekayaan intelektual di Indonesia dapat ditemukan dalam :

1.Undang-Undang Nomor 19 Tahun 2002 tentang Hak Cipta;

2.Undang-Undang Nomor 14 Tahun 2001 tentang Hak Paten;

3.Undang-Undang Nomor 15 Tahun 2001 tentang Hak Merek;

4.Undang-Undang Nomor 29 Tahun 2000 tentang Varietas Tanaman;

5.Undang-Undang Nomor 30 Tahun 2000 tentang Rahasia Dagang;

6.Undang-Undang Nomor 31 Tahun 2000 tentang Desain Industri;

7.Undang-Undang Nomor 32 Tahun 2000 tentang Desain Tata Letak Sirkuit Terpadu;

\section{HAK CIPTA}

\section{A. Pengertian Hak Cipta}

Hak eksklusif pencipta atau pemegang hak cipta untuk mengatur penggunaan hasil penaungan gagasan atau informasi tertentu. Dalam undang-undang hak cipta adalah hak eksklusif pencipta 
atau penerima hak untuk mengumumkan atau memperbanyak ciptaannya atau memberikan izin untuk itu dengan tidak mengurangi pembatasan-pembatasan menurut peraturan perundangundangan yang berlaku (pasal 1 butir 1). Dasar hukum Hak Cipta : Undang-Undang Nomor 19 Tahun 2002 tentang Hak Cipta.

\section{B.Masa Berlaku Hak Cipta}

Dalam Pasal 29 sampai dengan Pasal $34 \quad$ Undang-Undang Nomor 19 Tahun 2002 dalam Hak Cipta diatur masa/jangka waktu untuk suatu ciptaan. Dengan demikian, jangka waktu tergantung dari jenis ciptaan.

Hak cipta atas suatu ciptaan berlaku selama hidup pencipta dan terus menerus berlangsung hingga 50 tahun setelah pencipta meninggal dunia. Ciptaan yang dimiliki oleh dua orang atau lebih, hak cipta berlangsung selama hidup pencipta yang meninggal paling akhir dan berlangsung hingga 50 tahun setelah pencipta yang hidup terlama meninggal.

Hak atas ciptaan yang dimiliki atau dipegang oleh suatu badan hukum berlaku selama 50 tahun

Untuk perwajahan karya tulis yang diterbitkan berlaku selama 50 tahun sejak pertama kali diterbitkan.
Untuk ciptaan yang tidak diketahui siapa penciptanya dan peninggalan sejarah dan prasejarah benda budaya nasional dipegang oleh negara, jangka waktu berlaku tanpa batas waktu.

Untuk ciptaan yang belum diterbitkan dipegang oleh negara, ciptaan yang sudah diterbitkan sebagai pemegang hak cipta dan ciptaan sudah diterbitkan tidak diketahui pencipta dan penerbitnya dipegang oleh negara dengan jangka waktu selama 50 tahun sejak ciptaan tersebut pertama kali diketahui secara umum.

Untuk ciptaan yang sudah diterbitkan penerbit sebagai pemegang hak cipta jangka waktu berlaku selama 50 tahun sejak pertama kali diterbitkan.

\section{C.Pendaftaran Ciptaan}

Pendaftaran ciptaan dalam daftar umum ciptaan dilakukan atas permohonan yang diajukan oleh pencipta atau oleh pemegang hak cipta atau kuasa kepada Direktorat Jendral Hak Cipta, Paten, dan Hak Merek Departemen Kehakiman dan HAM. Dengan demikian, fungsi dari pendaftaran hak cipta hanyalah untuk mempermudah pembuktian jika ada sengketa. 


\section{D.Lisensi}

Pemegang hak cipta berhak memberikan lisensi kepada pihak lain berdasarkan surat perjanjian lisensi untuk melaksanakan perbuatan hukum selama jangka waktu lisensi dan berlaku untuk seluruh wilayah negara Republik Indonesia. Oleh karena itu, setiap perjanjian lisensi wajib dicatat pada Direktorat Jendral Hak Cipta.

E.Pelanggaran terhadap Hak Cipta

Pelanggaran terhadap hak cipta telah diatur dalam Pasal 72 dan Pasal 73 Undang-Undang Nomor 19 Tahun 2002 tentang Hak Cipta dapat dikenakan hukum pidana dan perampasan oleh negara untuk dimusnahkan.

\section{B. CONTENT}

Study kasus hak cipta tentang logo:

Perkara gugatan pelanggaran hak cipta logo cap jempol pada kemasan produk mesin cuci merek TCL bakal berlanjut ke Mahkamah Agung setelah pengusaha Junaide Sasongko melalui kuasa hukumnya mengajukan kasasi. "Kita akan mengajukan kasasi ke Mahkamah Agung (MA), rencana besok (hari ini) akan kami daftarkan," kata Angga Brata Rosihan, kuasa hukum
Junaide. Meskipun kasasi ke MA, Angga enggan berkomentar lebih lanjut terkait pertimbangan majelis hakim yang tidak menerima gugatan kliennya itu. "Kami akan menyiapkan buktibukti yang nanti akan kami tunjukan dalam kasasi," ujarnya. Sebelumnya, majelis hakim Pengadilan Niaga Jakarta Pusat mengatakan tidak dapat menerima gugatan Junaide terhadap Nurtjahja Tanudisastro, pemilik PT Ansa Mandiri Pratama, distributor dan perakit produk mesin cuci merek TCL di Indonesia.

Pertimbangan majelis hakim menolak gugatan tersebut antara lain gugatan itu salah pihak (error in persona). Kuasa hukum tergugat, Andi Simangunsong, menyambut gembira putusan Pengadilan Niaga tersebut. Menurut dia, adanya putusan itu membuktikan tidak terdapat pelanggaran hak cipta atas penggunaan logo cap jempol pada produk TCL di Indonesia. Sebelumnya, Junaide menggugat Nurtjahja karena menilai pemilik dari perusahaan distributor dan perakit produk TCL di Indonesia itu telah menggunakan logo cap jempol pada kemasan mesin cuci merek TCL tanpa izin. Dalam gugatanya itu. penggugat menuntut ganti rugi sebesar Rp 144 miliar.

Penggugat mengklaim pihaknya sebagai pemilik hak eksklusif atas logo cap jempol. Pasalnya dia mengklaim pemegang sertifikat hak cipta atas gambar 
jempol dengan judul garansi di bawah No.-C00200708581 yang dicatat dan diumumkan untuk pertama kalinya pada 18 Juni 2007. Junaide diketahui pernah bekerja di TCL China yang memproduksi AC merek TCL sekitar pada 2000-2007. Pada 2005. Junaide mempunya ide untuk menaikkan kepercayaan masyarakat terhadap produk TCL dengan membuat gambar jempol yang di bawahnya ditulis garansi. Menurut dia, Nurtjahja telah melanggar Pasal 56 dan Pasal 57 UU No. 19 tahun 2002 tentang Hak Cipta. Untuk itu Junaide menuntut ganti rugi materiel sebesar Rpl2 miliar dan imateriel sebesar Rp 120 miliar.

\section{CONCLUSION}

Setiap karya-karya yang lahir dari buah pikir yang cemerlang yang berguna bagi manusia perlu di akui dan dilindungi. Untuk itu sistem HAKI diperlukan sebagai bentuk penghargaan atas hasil karya.

Pengaturan hukum terhadap hak kekayaan intelektual di Indonesia dapat ditemukan dalam :

1.Undang-Undang Nomor 19 Tahun 2002 tentang Hak Cipta;

2.Undang-Undang Nomor 14 Tahun 2001 tentang Hak Paten;

3.Undang-Undang Nomor 15 Tahun 2001 tentang Hak Merek;
4.Undang-Undang Nomor 29 Tahun 2000 tentang Varietas Tanaman;

5.Undang-Undang Nomor 30 Tahun 2000 tentang Rahasia Dagang;

6.Undang-Undang Nomor 31 Tahun 2000 tentang Desain Industri;

7.Undang-Undang Nomor 32 Tahun 2000 tentang Desain Tata Letak Sirkuit Terpadu;

Disamping itu sistem HAKI menunjang diadakannya sistem dokumentasi yang baik atas segala bentuk kreativitas manusia sehingga kemungkinan dihasilkannya teknologi atau karya lainnya yang sama dapat dihindari atau dicegah.

Dengan dukungan dokumentasi yang baik tersebut, diharapkan masyarakat dapat memanfaatkannya dengan maksimal untuk keperluan hidupnya atau mengembangkannya lebih lanjut untuk memberikan nilai tambah yang lebih tinggi lagi. Kini masyarakat dalam melakukan pengajuan permohonan sudah tidak mengalami kesulitan karena Pemerintah melalui DITJEN HAKI telah banyak melakukan sosialisasi baik lewat media maupun forum-forum yang yang telah dibentuk. Sehingga akhirnya bagi pemilik hak tersebut tidak usah khawatir 
akan adanya kerugian yang diakibatkan oleh oknum yang tak bertanggung jawab yang ingin memanfaatkan kepopuleran merek suatu produk tertentu.

\section{DISCUSSION}

Prinsip-prinsip yang terdapat dalam hak kekayaan intelektual yaitu :

\section{Prinsip Ekonomi}

Prinsip ekonomi, yaitu hak intelektual berasal dari kegiatan kreatif suatu kemauan daya pikir manusia yang diekspresikan dalam berbagai bentuk yang akan memberikan keuntungan kepada pemilik yang bersangkutan.

2. Prinsip Keadilan

Prisip keadilan, yaitu di dalam menciptakan sebuah karya atau orang yang bekerja membuahkan hasil suatu dari kemampuan intelektual dalam imu pengetahuan, seni, dan sastra yang akan mendapat perlindungan dalam pemilikannya.

\section{Prinsip Kebudayaan}

Prinsip kebudayaan, yaitu perkembangan ilmu pengetahuan, sastra dan seni untuk meningkatkan kehidupan manusia. Dengan menciptakan suatu karya dapat meningkatkan taraf kehidupan, peradaban, dan martabat manusia yang akan memberikan keuntungan bagi masyarakat, bangsa, dan negara.

4. Prinsip Sosial

Prinsip sosial (mengatur kepentingan manusia sebagai warga negara), artinya hak yang diakui oleh hukum dan telah diberikan kepada individu merupakan suatu kesatuan sehingga perlindungan diberikan berdasarkan keseimbangan kepentingan individu dan masyarakat.

Perkara gugatan pelanggaran hak cipta logo cap jempol pada kemasan produk mesin cuci merek TCL bakal berlanjut ke Mahkamah Agung setelah pengusaha Junaide Sasongko melalui kuasa hukumnya mengajukan kasasi. "Kita akan mengajukan kasasi ke Mahkamah Agung (MA), rencana besok (hari ini) akan kami daftarkan," kata Angga Brata Rosihan, kuasa hukum Junaide. Meskipun kasasi ke MA, Angga enggan berkomentar lebih lanjut terkait pertimbangan majelis hakim yang tidak menerima gugatan kliennya itu. "Kami akan menyiapkan buktibukti yang nanti akan kami tunjukan dalam kasasi," ujarnya. Sebelumnya, majelis hakim Pengadilan Niaga Jakarta Pusat mengatakan tidak dapat menerima gugatan Junaide terhadap Nurtjahja Tanudisastro, pemilik PT Ansa Mandiri Pratama, distributor dan perakit produk mesin cuci merek TCL di Indonesia. 
Pertimbangan majelis hakim menolak gugatan tersebut antara lain gugatan itu salah pihak (error in persona). Kuasa hukum tergugat, Andi Simangunsong, menyambut gembira putusan Pengadilan Niaga tersebut. Menurut dia, adanya putusan itu membuktikan tidak terdapat pelanggaran hak cipta atas penggunaan logo cap jempol pada produk TCL di Indonesia. Sebelumnya, Junaide menggugat Nurtjahja karena menilai pemilik dari perusahaan distributor dan perakit produk TCL di Indonesia itu telah menggunakan logo cap jempol pada kemasan mesin cuci merek TCL tanpa izin. Dalam gugatanya itu. penggugat menuntut ganti rugi sebesar Rp 144 miliar.

Penggugat mengklaim pihaknya sebagai pemilik hak eksklusif atas logo cap jempol. Pasalnya dia mengklaim pemegang sertifikat hak cipta atas gambar jempol dengan judul garansi di bawah No.C00200708581 yang dicatat dan diumumkan untuk pertama kalinya pada 18 Juni 2007. 


\section{E. REFERENCE}

[1] O. M. Febriani and A. S. Putra, "Sistem Informasi Monitoring Inventori Barang Pada Balai Riset Standardisasi Industri Bandar Lampung," J. Inform., vol. 13, no. 1, pp. 90-98, 2014.

[2] A. S. Putra, "Paperplain: Execution Fundamental Create Application With Borland Delphi 7.0 University Of Mitra Indonesia," 2018.

[3] A. S. Putra, "2018 Artikel Struktur Data, Audit Dan Jaringan Komputer," 2018.

[4] A. S. Putra, "ALIAS MANAGER USED IN DATABASE DESKTOP STUDI CASE DB DEMOS."

A. $\mathrm{S}$.

Putra, "COMPREHENSIVE SET OF PROFESSIONAL FOR DISTRIBUTE COMPUTING."

[6] A. S. Putra, "DATA ORIENTED RECOGNITION IN BORLAND DELPHI 7.0."

[7] A. S. Putra, "EMBARCADERO DELPHI XE 2 IN GPUPOWERED FIREMONKEY APPLICATION."

[8] A. S. Putra, "HAK ATAS KEKAYAAN INTELEKTUAL DALAM DUNIA TEKNOLOGY BERBASIS REVOLUSI INDUSTRI 4.0."

[9] A. S. Putra, "IMPLEMENTASI PERATURAN
PERUNDANGAN UU. NO 31

TAHUN 2000 TENTANG DESAIN INDUSTRI BERBASIS INFORMATION TECHNOLOGY."

[10] A. S. Putra, "IMPLEMENTATION OF PARADOX DBASE."

[11] A. S. Putra, "IMPLEMENTATION OF TRADE SECRET CASE STUDY SAMSUNG MOBILE PHONE."

[12] A. S. Putra, "IMPLEMENTATION

PATENT FOR APPLICATION WEB BASED CASE STUDI WWW. PUBLIKLAMPUNG. COM."

[13] A. S. Putra, "IMPLEMENTATION SYSTEM FIRST TO INVENT IN DIGITALLY INDUSTRY."

[14] A. S. Putra, "MANUAL REPORT \& INTEGRATED DEVELOPMENT

ENVIRONMENT BORLAND DELPHI 7.0."

[15] A. S. Putra, "PATENT AS RELEVAN SUPPORT RESEARCH."

[16] A. S. Putra, "PATENT FOR RESEARCH STUDY CASE OF APPLE. Inc."

[17] A. S. Putra, "PATENT PROTECTION FOR APPLICATION INVENT."

[18] A. S. Putra, "QUICK REPORT IN PROGRAMMING."

[19] A. S. Putra, "REVIEW CIRCUIT LAYOUT COMPONENT

REQUIREMENT ON ASUS NOTEBOOK." 
[20] A. S. Putra, "REVIEW TRADEMARK PATENT FOR INDUSTRIAL TECHNOLOGY BASED 4.0."

[21] A. S. Putra, "TOOLBAR COMPONENT PALLETTE IN OBJECT ORIENTED PROGRAMMING."

[22] A. S. Putra, "WORKING DIRECTORY SET FOR PARADOX 7."

[23] A. S. Putra, "ZQUERY CONNECTION

IMPLEMENTED

PROGRAMMING

STUDI

CASE PT. BANK BCA Tbk."

[24] A. S. Putra, D. R. Aryanti, and I. Hartati, "Metode SAW (Simple Additive Weighting) sebagai Sistem Pendukung Keputusan Guru Berprestasi (Studi Kasus: SMK Global Surya)," in Prosiding Seminar Nasional Darmajaya, 2018, vol. 1, no. 1, pp. 85-97.

[25] A. S. Putra and O. M. Febriani, "Knowledge Management Online Application in PDAM Lampung Province," in Prosiding International conference on Information Technology and Business (ICITB), 2018, pp. 181-187.

[26] A. S. Putra, O. M. Febriani, and B. Bachry, "Implementasi Genetic Fuzzy System Untuk Mengidentifikasi Hasil Curian Kendaraan Bermotor Di Polda Lampung," SIMADA (Jurnal Sist. Inf. dan Manaj. Basis Data), vol. 1, no. 1, pp. 21-30, 2018.

[27] A. S. Putra, H. Sukri, and K. Zuhri, "Sistem Monitoring Realtime Jaringan Irigasi Desa
(JIDES) Dengan Konsep Jaringan Sensor Nirkabel," IJEIS (Indonesian J. Electron. Instrum. Syst., vol. 8, no. 2, pp. 221-232.

[28] D. P. Sari, O. M. Febriani, and A. S. Putra, "Perancangan Sistem Informasi SDM Berprestasi pada SD Global Surya," in Prosiding Seminar Nasional Darmajaya, 2018, vol. 1, no. 1, pp. 289-294. 